NBER WORKING PAPER SERIES

\title{
RELATIVE RETURNS ON EQUITIES \\ IN PACIFIC BASIN COUNTRIES
}

Charles Engel

John H. Rogers

Working Paper No. 4655

\section{NATIONAL BUREAU OF ECONOMIC RESEARCH \\ 1050 Massachusetts Avenue \\ Cambridge, MA 02138 \\ February 1994}

This paper was prepared for the conference volume Exchange Rate Policy and

Interdependence: Perspectives from the Pacific Basin, edited by Reuven Glick and Michael Hutchinson. We would like to thank the editors for constructive comments. This paper is part of NBER's research program in International Finance and Macroeconomics. Any opinions expressed are those of the authors and not those of the National Bureau of Economic Research. 


\title{
RELATIVE RETURNS ON EQUTTIES IN PACIFIC BASIN COUNTRIES
}

\begin{abstract}
We examine the factors that determine the differences in ex ante returns on equities in eleven Pacific Basin countries. Our concern is whether real return differentials are primarily caused by nominal return differentials or expected changes in real exchange rates. We find that nominal return differentials account for most of the difference, which suggests that either there is not free mobility of capital between the countries of our study or that there are significant differences in the riskiness of returns across countries. We do not find a significant relationship between the size of the return differentials and the flexibility of the nominal exchange rate.
\end{abstract}

Charles Engel

Department of Economics

University of Washington

Seattle, WA 98195

and NBER
John H. Rogers

Department of Economics

Pennsylvania State University

$613 \mathrm{Kem}$ Graduate Building

University Park, PA 16802 


\section{Capital Mobility}

Equity markets have grown rapidly and restrictions on investments have declined equally rapidly in Pacific Basin countries in the 1980s. The return on equities now provides a good measure of the opportunity cost of capital in the eleven countries that are the focus of this study: Australia, Canada, Chile, Japan, Korea, Malaysia, Mexico, Singapore, Taiwan, Thailand and the United States.

The purpose of equity markets is to allocate capital to its most efficient use. In the absence of uncertainty, efficient equity markets ensure that the marginal product of capital is equalized among its various uses. In the presence of uncertainty, equity markets price assets to reflect not only the expected return on the asset, but the riskiness of projects as well.

A great deal of attention has been focused in recent years on the international mobility of capital. If there are restrictions on capital flows between countries, then investors will not be able to allocate their resources toward their most desirable use. There appears to have been a global trend toward liberalization of capital markets and toward allowing foreigners access to local markets. However, there is no consensus as to whether these moves have achieved true integration of international capital markets.

Feldstein and Horioka (1980) questioned the degree of integration of international capital markets. They argued that if capital could flow freely between countries that savers would have no bias toward channeling their funds toward domestic projects. If capital markets allocated savings efficiently, then the savings of residents of one country should be just as likely to be used to fund investments in foreign countries as 
to fund capital projects at home. So, we should not expect to see a close relation between the level of saving in a country and the level of investment. There is no particular reason why high saving countries should also be countries with excellent investment opportunities.

However, in examining a cross-section of OECD countries over the period 1960-1974, Feldstein and Horioka found a strong correlation between national saving/GDP ratios and investment/GDP ratios. The simple correlation coefficient is greater than .90 . The authors interpret their findings as evidence of barriers to the international flow of funds: "...if portfolio preferences and institutional rigidities impede the flow of longterm capital among countries, increases in domestic saving will be reflected primarily in additional domestic investment."

The findings of Feldstein and Horioka are surprising and have led many economists to search for ways to reconcile these conclusions with the observation that there are few restrictions on capital flows among OECD countries, and that transactions costs have fallen to very low levels. While many explanations for Feldstein and Horioka's results have emerged over the years, perhaps the most compelling has been offered by Frankel (1986, 1991). Frankel makes a distinction between portfolio capital and physical capital. Investment, as measured by Feldstein and Horioka, refers to the accumulation of physical capital. However, when economists speak of international capital mobility, they are not referring to the movement of physical capital. It is clear that moving actual machines and factories would be very costly. Nobody would describe such movements as "free". Mobility of capital, instead, refers to the movement of portfolio capital.

In essence, Feldstein and Horioka's theory is that international mobility of capital would equalize risk-adjusted ex ante real rates of return. With real rates of return the same across countries, there would be no reason for savers to channel their funds exclusively to home projects. Indeed, if a desirable investment opportunity arises 
abroad, the marginal product of capital, and therefore the real return on investment, is pushed up temporarily in that foreign country. Then, capital will flow to that country until the real return there is drawn back into equality with ex ante real returns in other countries.

Thus, letting $r_{t+1}^{j}$ equal the real rate of return between period $t$ and period $t+1$ in country $j$, and letting $r_{i+1}^{k}$ be the analogous return for country $k$, the Feldstein-Horioka null hypothesis is that free international capital mobility implies

(1) $\operatorname{Errt+1}_{i t i+1}^{j}-E_{i}^{k}=0$,

for all countries $j$ and $k$. In this expression, $E_{\mathbf{l}}$ refers to the expectations that investors form at time $t$ (so that, for example, $\mathrm{E}_{t} \mathrm{r}_{t+1}^{\mathrm{j}}$ is the expectation at time $t$ of the real rate of return between time $t$ and $t+1$ in country $j$.)

Frankel, however, notes that relationship (1) is really a condition that one would expect to hold if physical capital were free to move internationally. Then, efficient markets would insure that the real returns to owners of capital are the same, irrespective of the location of the capital.

However, as noted above, few economists interpret the notion of capital mobility as applying to actual machines and factories. If the ex ante return on capital is temporarily high in some country, economists do not envision entrepreneurs unbolting machines and disassembling factories to ship them over to the country with the high rate of return. Instead, portfolio capital will flow to that country. Funds will be made available so that entrepreneurs can build new factories in the country where the marginal product of capital is high.

Frankel notes that free mobility of portfolio capital will result in the equalization of the nominal rate of return on investments, adjusted for expectations of currency depreciation. That is, when capital flows freely, investors should expect the same return on funds that are kept at home and funds that are sent abroad: 


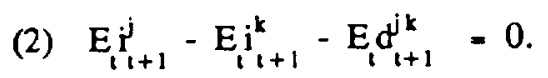

In this equation, $\mathrm{i}$ is the nominal rate of return. So, $\mathrm{E}_{i+1}^{\mathrm{j}}$ is the rate of return in country $j$, denominated in the currency of country $j$, that investors expect between time $t$ and $t+1$, while $\mathrm{E}_{\mathrm{i}}^{\mathrm{k}} \mathrm{t+1}$ is the analogous rate of return for country $\mathrm{k}$. To make these two rates of return comparable, they must be converted into a common currency. We use the symbol $d_{t+1}^{j k}$ to refer to the rate of depreciation of currency $j$ relative to currency $k$ between time $t$ and $t+1$. So, $E_{i t+1}^{j k}$ is the expected rate of depreciation of currency $j$ at time t. Equation (2) says that free mobility of portfolio capital implies that the expected nominal returns on investments in any two countries $\mathbf{j}$ and $\mathbf{k}$, when expressed in a common currency, will be equalized.

What is the difference between expression (1) which states that ex ante real returns are the same, and equation (2) which indicates the equality of expected nominal returns? We can write the expected real return in country $j$ as

(3) $\mathrm{E}_{i 1+1}^{\mathrm{j}}=\mathrm{E}_{i+1}^{\mathrm{j}} \cdot \mathrm{E}_{i+1}^{\mathrm{j}}$.

Here, $E_{1} \pi_{1+1}^{j}$ is the rate of inflation of country $j$ 's prices that is expected to occur between time $t$ and $t+1$. Using relation (3), we can write the difference in the ex ante real rates of return as

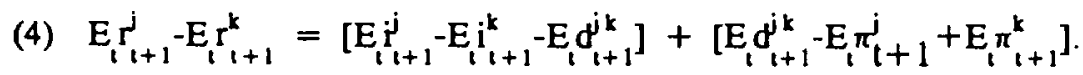

The first bracketed term on the right hand side of equation (4) is the ex ante nominal return differential, as in equation (2). The ex ante nominal return differential does not equal the expected real return differential unless the second bracketed term on the right side of equation (4) is zero. That term is the expected change in the real value of currency $j$ relative to currency $k$. Thus, the real return condition expressed in equation (1) is equivalent to the nominal retum condition in equation (2) if and only if ex ante purchasing power parity (PPP) holds.

So, investment projects in one country may indeed have a higher expected real 
return than investment projects in another country, even if there is perfect international mobility of portfolio capital. That can occur as long as the expected change in the real exchange rate is not zero. Fconomists have long understood conditions under which ex ante PPP would not hold, and these conditions are not necessarily related to the presence or absence of capital controls. For example, Dornbusch (1976) examines the behavior of exchange rates and interest rates in a model with perfect capital mobility, but one in which PPP fails to hold because nominal goods prices are "sticky". That is, in Dornbusch's framework, in the long-run equilibrium prices adjust toward PPP, but this adjustment occurs only gradually over time. Thus, deviations from PPP persist for long periods. In Dombusch's extended Mundell-Fleming framework, national saving and investment rates can be highly correlated even in the presence of free portfolio capital mobility. Other authors (for example, Razin (1984)) have emphasized that PPP need not be a condition of equilibrium in the market for goods when there are non-traded goods. Engel and Kletzer (1989) show that in general one should expect to find a high correlation between the level of saving and investment in countries when non-traded goods are present.

While Feldstein and Horioka and most of the subsequent related literature has focused on capital mobility in OECD countries, there has recently developed considerable interest in the nature of capital flows among Pacific Rim countries. In part that interest has arisen naturally from the increased capital flows that have occurred between these countries which was spurred by the widespread liberalization of capital markets and financial reforms that occurred in this region in the 1970s and 1980s. (See Cheng (1986) for a collection of papers that extensively studies these issues.) Of particular interest for our purposes has been the concomitant expansion of local equity markets in the region. As these markets have developed, the opportunities for intemational investors who are seeking high return or diversification have expanded. In this study, 
we will explore the success of these equity markets equalizing real returns on investment opportunities.

In particular, we will focus on the issue raised by Frankel: Do real returns between countries differ because ex ante nominal rates of return are different, or because ex ante purchasing power parity fails to hold? We develop a measure of the relative importance of these two components of real return differentials in explaining the average difference in expected real returns on equities across pairs of countries on the Pacific Rim.

Our findings show that generally it is the ex ante nominal return differentials that account for most of the difference in real return prospects for equity investors across countries. This result holds across most pairs of countries in the region, although it is not universal.

We focus on whether the exchange rate arrangements of the various countries influences the importance of nominal return differentials versus deviations from PPP in explaining ex ante real return differentials. Our findings are that there does not appear to be any consistent relation between the types of exchange rate arrangements and the relative strength of the two components.

In reaching the conclusion that most of the difference in real returns is attributable to the gap between expected nominal returns, we have not been able to adjust for risk. Hence, while our findings may imply that there are still important restrictions to the flow of financial capital among Pacific Rim countries that prevents the equalization of ex ante nominal returns, it is also possible that the differences in returns stem from the difference in the relative riskiness of the equity investments.

In section II of this paper, we present the methods we employ for measuring the relative strength of deviations from ex ante nominal returns equality versus ex ante PPP. Our methods are related to those of Frankel (1991, 1992), Chinn and Frankel (1992), Glick 
(1987) and Glick and Hutchison (1990) which focus on markets for lending rather than equity markets.

Section III discusses the nature of restrictions on investments in equity markets in the Pacific Rim and the types of foreign exchange rate systems that prevail in these countries. We also discuss the data that we use in our empirical study.

Section IV presents the results of our study, and discusses the forces that lead to different degrees of influence of financial market versus goods market integration in the Pacific Basin. In section $\mathrm{V}$ we offer some conclusions and discuss the implications of our findings.

\section{Decomposing the Real Retum Differential}

In this section, we present a method for decomposing movements in the expected real retum differential into a fraction attributable to changes in the ex ante nominal return differential and the rest to movements in ex ante deviations from PPP.

Initially, let us assume that we can measure expectations of investors completely accurately. Of course, in reality we cannot, so in a moment we will turn to how we derive a measure of expectations, and what to do about the fact that the measure is not one hundred per cent accurate. First, however, assume that we observe $y_{1} \equiv E_{t} r_{t+1}^{j}-$

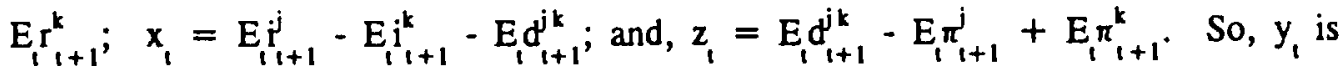
the expected real interest differential, $x_{1}$ is the expected nominal interest differential, and $z_{t}$ are expected deviations from PPP.

With these definitions $y_{1} \equiv x_{1}+z_{i}$. We would like to know what makes $y_{1}$ differ from zero. That is, what makes the real interest differential at any time non-zero? Is it because $x_{i}$ is different from zero, or $z_{i}$ ?

One way one might think about measuring this is to calculate the average values of 
$y, x$ and $z$, and then look at the ratio of the mean of $x$ to the mean of $y$ and the mean of $z$ to the mean of $y$. One problem with this approach is that over time $y$ might fluctuate between positive and negative. Its average might be low, but it may be substantially different from zero in every period. So, the looking at the mean of $y$ might conceal the fact that the expected real interest differential is consistently non-zero.

We could avoid that problem by considering, for example, the average of the absolute values of $y, x$ and $z$, or the average of the squared values of $y, x$ and $z$. But this approach does not solve another problem -- suppose that $x$ tends to be negative in periods when $y$ is positive. Then, it would be misleading to say that large values of the square of $x$ are associated with large values of the square of $y$. When $y$ is positive but $\mathrm{x}$ is negative, $\mathrm{z}$ is pulling $\mathrm{y}$ above zero, and $\mathrm{x}$ is dragging it back down, so $\mathrm{x}$ is not responsible for making y non-zero.

An alternative decomposition is to calculate the sample non-central second moments: $\hat{m}(y, y) \equiv \frac{1}{T} \sum y_{t}^{2} ; \hat{m}(x, y) \equiv \frac{1}{T} \sum x_{t} y_{t} ;$ etc. (where $T$ is the number of observations.) Since $\hat{m}(y, y)=\hat{m}(x, y)+\hat{m}(z, y)$, it is natural to attribute to $x$ the ratio $\hat{m}(x, y) / \hat{m}(y, y)$ of the average squared deviation of $y$ from zero, and to attribute to $z$ the remainder, $\hat{\mathrm{m}}(z, y) / \hat{m}(y, y)$. For example, suppose that every period $y=5, x=10$ and $z=-5$. Then, under this decomposition, we have that $2.0(200 \%)$ of the average deviation of $y^{2}$ from 0 comes from $x$ being different from zero, while $-1.0(-100 \%)$ comes from $z$. That makes sense here, because $y$ is always positive, but $z$ is always negative. So, $z$ tends to draw $y$ toward zero, but it is being pulled away from zero in the positive direction by the large positive values of $x$. On the other hand, if for example every period $y=5, x=4$ and $z=1$, the fraction of the deviation we attribute to $x$ is $4 / 5$ and to $z, 1 / 5$.

In practice we cannot measure $y, x$ and $z$ exactly. We will assume that we measure expectations with error. Below we discuss precisely how we construct a measure of 
investors' expectations. So, we observe only $y^{\circ}, x^{\circ}$, and $z^{\circ}$, which are related to the actual expectations by the following equations:

$$
\begin{aligned}
& y_{1}^{0}=y_{1}+\varepsilon_{1}^{y}, \\
& x_{1}^{o}=x_{1}+\varepsilon_{1}^{x}, \text { and } \\
& z_{1}^{o}=z_{1}+\varepsilon_{1}^{z} .
\end{aligned}
$$

The $\varepsilon$ represent measurement error terms.

We would like to measure $\frac{\hat{m}(x, y)}{\hat{m}(y, y)}$, but we do not observe either $x$ or $y$ (or $z$ ). We $m(y, y)$

propose using $\frac{\hat{m}\left(x^{\circ}, y^{\circ}\right)}{m\left(y^{\circ}, y^{\circ}\right)}$ as an approximation to $\frac{\hat{m}(x, y)}{\hat{m}(y, y)}$. We can write:

$$
\frac{\hat{m}\left(x^{0}, y^{0}\right)}{\hat{m}\left(y^{0}, y^{q}\right)}=\frac{\hat{m}(x, y)+\hat{m}\left(y, \varepsilon^{x}\right)+\hat{m}\left(x, \varepsilon^{y}\right)+\hat{m}\left(\varepsilon^{x}, \varepsilon^{y}\right)}{\hat{m}(y, y)+2 \hat{m}\left(y, \varepsilon^{y}\right)+\hat{m}\left(\varepsilon^{y}, \varepsilon^{y}\right)} \text {. }
$$

Clearly, $\frac{\hat{m}\left(x^{0}, y^{0}\right)}{\hat{m}\left(y^{0}, y^{0}\right)}$ does not exactly equal $\frac{\hat{m}(x, y)}{\hat{m}(y, y)}$.

If the difference between our measured expectations and the true expectations is pure measurement error, then it is probably plausible to assume that the measurement errors have means of zero, and are uncorrelated with $y, x$ and $z$. Let $m 0$ represent the population moment that is consistently estimated by $\hat{\mathrm{m}} 0$. Then, our assumption is that the moments $m\left(j, \varepsilon^{k}\right)$ for $j, k=x, y, z$, are zero. Imposing this, (and replacing sample moments with population moments from the above equation) we have

$$
\frac{m\left(x^{\circ}, y^{q}\right)}{m\left(y^{0}, y^{q}\right)}=\frac{m(x, y)+m\left(\varepsilon^{x}, \varepsilon^{y}\right)}{m(y, y)+\cdot m\left(\varepsilon^{y}, \varepsilon^{y}\right)} .
$$


Thus, $\frac{m\left(x^{\circ}, y^{0}\right)}{m\left(y^{\circ}, y^{\circ}\right)}$ will equal $\frac{m(x, y)}{m(y, y)}$ as long as

$$
\frac{m\left(\varepsilon^{x}, \varepsilon^{y}\right)}{m\left(\varepsilon^{y}, \varepsilon^{y}\right)}=\frac{m(x, y)}{m(y, y)}
$$

Intuitively, this condition is just that the measurement error of $\mathrm{x}$ contributes as much to the measurement error of $y$ as $x$ contributes to the deviation of $y$ from zero.

Even if we do not accept the assumption under which $\frac{m\left(x^{0}, y^{0}\right)}{m\left(y^{0}, y^{0}\right)}$ equals $\frac{m(x, y)}{m(y, y)}$, so we do not believe that we can accurately measure the share of deviations of $y$ from zero that are attributable to $x$, we can compare these shares across countries under much weaker assumptions. Much of our analysis of section 4 consists of precisely this type of comparison. We ask, for example, whether countries with more flexible exchange rates tend to have larger ex ante real return differentials because of fluctuations in the ex ante nominal return differentials or in the ex ante deviations from PPP. We can make the fairly innocuous assumptions that the noise to signal ratios are constant across countries:

$$
\begin{aligned}
& \frac{m\left(\varepsilon^{x}, \varepsilon^{y}\right)}{m(x, y)}=\alpha, \text { and } \\
& \frac{m\left(\varepsilon^{y}, \varepsilon^{y}\right)}{m(y, y)}=\beta,
\end{aligned}
$$

but without imposing the requirement that $\alpha=\beta$. With these assumptions, we have that

$$
\frac{m\left(x^{0}, y^{0}\right)}{m\left(y^{0}, y^{0}\right)}=\frac{m(x, y)}{m(y, y)} \cdot\left(\frac{1+\alpha}{1+\beta}\right) .
$$


Under these assumptions, $\frac{m(x, y)}{m(y, y)}$ is not equal to $\frac{m\left(x^{0}, y^{0}\right)}{m\left(y^{0}, y^{0}\right)}$, but in all countries the measurement is off by a scale factor of $\frac{1+\alpha}{1+\beta}$. Thus, our measure correctly orders countries by the size of $\frac{m(x, y)}{m(y, y)}$, even if we cannot measure that ratio consistently. We now tum to the construction of our measures of the ex ante real return differential, $y_{1}=E_{t+1}^{j}-E_{t+1}^{j} r_{t+1}^{j}$ the ex ante nominal return differential, $x_{1}=E_{i t+1}^{j}$ - $E_{t i+1}^{i_{1}^{k}}-E_{t} d_{t+1}^{j k} ;$ and, the ex ante deviation from PPP, $z_{t}=E_{t} d_{t+1}^{j k}-E_{t} \pi_{t+1}^{j}+E_{i} \pi_{t+1}^{k}$. Our measure of these variables are real time forecasts based on lagged values of $i_{t+1}^{j} j_{t+1}^{-k^{k}}-d_{t+1}^{j k}, d_{t+1}^{j k}-\pi_{t+1}^{j}+\pi_{t+1}^{k}$, and lags of the squares of $r_{t+1}^{j}-r_{t+1}^{k}, i_{t+1}^{j}-i_{t+1}^{k}-d_{t+1}^{j k}$, and $d_{t+1}^{j k}-\pi_{t+1}^{j}+\pi_{t+1}^{k}$. For example, suppose that we wish to derive the expectation at time $s$ of $r_{s+1}^{j}-r_{t+1}^{k}$. Then, we perform the regression of $r_{t}^{j}-r_{t}^{k}$ on $i_{t-1}^{j}-i_{t-1}^{k}-d_{t-1}^{j k}, d_{t-1}^{j k}-\pi_{t-1}^{j}+\pi_{t-1}^{k}$, and the squares of $r_{t-1}^{j}-r_{t-1}^{k}, i_{t-1}^{j}-i_{t-1}^{k}-d_{t-1}^{j k}$, and $d_{t-1}^{j k}-\pi_{t-1}^{j}+\pi_{t-1}^{k}$, with data on $r_{t}^{j}-r_{1}^{k}$ up to time $s$. Then we use time $s$ data to forecast $r_{a+1}^{j}-r^{k}$. Then, to forecast $r_{i+2}^{j}-r_{a+2}^{k}$ we reestimate the forecasting equation using data through time $s+1$. Hence, we get "rolling" or "real time" forecasts of each of the variables.

We use only one lag of the various variables as forecasters, for several reasons. First, as we discuss in the next section, we examine a relatively short time series on equity returns. In part, this stems from the fact that only fairly recently have the equity markets in many of the countries we examine become very large and open to foreign investment. We also must use two years and one month of data to derive our first forecast. So, the limited run of data constrains the number of lags that can be used in the forecasting equation. In addition, we do not want to overfit the equation. In preliminary work which is not reported, we added some right hand side variables such as 
the deviation of last month's value of the return differential from its average over the prior six months. We found that such variables were usually not significant in the regressions and did not improve the forecasting performance.

The deviation of our measure of the agents' expectations from their true expectations will satisfy the properties stipulated above -- that is, have a mean of zero and be uncorrelated with $x, y, z$ and the other measurement errors -- when two conditions are met. First, we assume that investors have rational expectations. Hence, they use all available information in an efficient way to construct their forecasts. We, as econometricians, do not know precisely which variables agents use in deriving their forecasts. The error we make in measuring the investors' expectations arises because we leave out variables from our forecasting equation that investors use in arriving at their expectations. So, our second condition is that the marginal forecasting ability of the left-out variables be uncorrelated with the variables we include in the forecasting equation. (That is, construct the forecast errors from our equation. If those we took the fitted values of the projection of those errors onto the left-out variables, those fitted values should be uncorrelated with our included right hand side variables.)

An alternative way of measuring expectations would be to follow the lead of Frankel and Froot (1987), Froot and Frankel (1989) and Chinn and Frankel (1992) and use survey data. Although arguably there would still be some measurement error in expectations because the surveys might not cover comprehensively the relevant actors in the equity markets, it is a good bet that such surveys provide more accurate measures of expectations than the ones we construct. Unfortunately, we can find no surveys of investors' expectations of equity returns, inflation and currency depreciation for most of the countries in our study. 
III. Equity Markets and Foreign Exchange Markets in the Pacific Basin

We examine the behavior of equity returns from eleven countries that surround the Pacific Ocean -- Japan, Canada, Australia, Chile, Korea, Malaysia, Mexico, Singapore, Taiwan, Thailand and the United States. We use data on equity returns beginning in September 1983 (with the exception of Taiwan, whose data begin in January 1986). Our first forecast is for 25 months after the starting date of the data (October 1985 in most instances). The data end in 1991 for most countries, and in 1990 for the rest.

Equity trading in Australia occurs on the Australian Stock Exchange in Sydney. Share trading began in Sydney in 1828, with shares of a single company being traded. Today there are essentially no restrictions on foreign investment in shares, and foreigners are allowed membership on the exchange. The only minor restriction is imposed by Australia's Foreign Take-over Act which limits foreign ownership of a firm to $15 \%$ of the firm's value for a single investor. ${ }^{1}$ Our stock index data for Australia are from the All Ordinary Index. Our stock return data are taken from the Datastream International tape for all countries except Chile, and are middle of the month, end of trading day.

Three-quarters of trades in shares in Canada occurs on the Toronto Stock Exchange. The only restrictions on foreign investment in Canada are limits on foreign control of certain companies such as banks. Foreigners are not allowed to be members of the Toronto Stock Exchange, but membership is open on the Bourse de Montreal. The Toronto stock exchange began trading in 1852 , but informal trading began in Montreal in the $1820 \mathrm{~s}$. The stock return data for Canada come from the Toronto Stock Exchange Composite Index.

The Bolsa de Comercio de Santiago handles share trading in Chile. Trading began in

\footnotetext{
1 Most of our information on the nature of restrictions on international investment in markets comes from either the 1990 edition of Emerging Stock Markets Factbook of the International Finance Corporation, or the 1988 edition of the Directory of World Stock Exchanges compiled by the Economist.
} 
Chile in 1893, and the markets have been relatively free since the liberalizations that occurred in 1973. Chile underwent a severe financial crisis in the early 1980s, but the stock market appears to have recovered by the mid-1980s. There are no restrictions on the remittance of income earned by foreigners on the Chilean stock market, but the initial capital invested must remain in Chile for at least three years. Foreigners are allowed membership in the stock exchange. Our Chilean stock return series is taken from International Financial Statistics published by the International Monetary Fund.

The Tokyo Stock Exchange has been trading since 1878. There are essentially no restrictions on foreign investment, and foreign brokers can obtain seats on the Exchange. We use the Nikkei Dow Jones Average Index.

The Korean Stock Exchange was founded in Seoul in 1956. Until very recently there have been severe limitations on investments by foreigners. Investment and repatriation was subject to approval by the Ministry of Finance. However, foreigners could invest through international investment trusts, the Korea fund and the Korea-Europe fund. In January 1992, there was initiated a significant liberalization of the restrictions on foreign investment, so that the major restrictions now require ownership of less than $10 \%$ of the shares of any one company. Our Korean stock return data are constructed from the Korea South Composite Index.

In Malaysia, trading occurs on the Kuala Lumpur Stock Exchange. The market is essentially open to foreigners -- they may obtain membership and trading is subject only to the restriction that acquisitions exceeding $M \$ 5$ million must be approved by the Foreign Investment Committee. Investment is also possible for foreigners through a mutual fund traded on international markets. We use the Financial Times Actuaries Index for our data on Malaysian returns.

Trading on the Malay Peninsula dates back to the late nineteenth century, and, in 1930, the Singapore Stockbrokers Association became the first organized exchange. In 
1960 the Malayan Stock Exchange was chartered with trading in Singapore and Kuala Lumpur. When Singapore seceded from the Federation of Malaysia in 1965 it remained in the stock exchange. The Stock Exchange of Singapore did not become an independent organization until 1973. There are virtually no restrictions on foreign investment (there are some requirements concerning the degree of foreign ownership of banks and newspapers) and foreign brokers are allowed membership on the Singapore exchange. Our stock returns are calculated from the Straits Times Index.

Mexico's share trading occurs at the Bolsa Mexicana de Valores in Mexico City. Stock trading began there in 1894 . Until the late 1980s there were a few significant restrictions on foreign investments. Foreigners were not allowed seats on the exchange, and foreign investors could not own shares in some industries: petroleum, petrochemical, development of radioactive materials, some mining, electricity, railroads, telegraph, radio and television, transport, national air transport and maritime companies, forest exploitation and gas distribution. There has been considerable liberalization since Carlos Salinas became President, however. In addition, a Mexico Fund is traded on the New York Stock Exchange. For Mexico, we use data from the Financial Times Actuaries Index.

In Taiwan, the Taipei Stock Exchange Corporation began trading in 1961. Foreign nationals can trade under certain regulations, but otherwise investing for foreigners is limited to closed-end mutual funds traded on the U.S. and European markets. The Taiwan Weighted Index is the source of our stock returns for this country.

The Securities Exchange of Thailand (SET) trades securities in Bangkok. It began trading in 1975 and is now fairly open to foreigners, except for restrictions which prevent foreign interests from becoming majority shareholders. In addition, closed-end mutual funds are traded on international markets. We use the SET Index for our stock return data for Thailand. 
There are several stock exchanges in the United States, the largest of which is the New York Stock Exchange. The NYSE began using that name in 1863 , but share trading began there in 1792. There are no rules for foreign investors that differ from those imposed on domestic residents. We use returns from the Standard and Poor's 500 Index.

Table 1, from the 1990 edition of the Emerging Stock Markets Eactbook, indicates the rapid growth in the markets we focus on. In the 1980 s generally there was a sharp increase in the number of different firms whose shares were traded - particularly in the smaller markets -- and the dollar value of shares traded expanded by a large factor in all eleven countries.

In the period covered by our study on expected stock market returns (post-October 1985), many of our countries maintained essentially freely floating exchange rates. The U.S., Canada, Japan and Australia can be characterized in this manner. The other seven countries can be said to have been under managed floating regimes during the period of our study. While some of these countries were officially pegging to a basket of currencies, many of the rest were in essence unofficially following such a policy (see the calculation of the basket weights in Frankel and Wei (1992)). All seven could be characterized as having a "managed float". Hence, we will pay special attention to the behavior of retums of the first four countries as compared to the other seven.

For most of the countries, the foreign exchange rate data are from the Datastream International tape. However, for Korea, Chile, Thailand and Mexico they are from International Financial Statistics. For Taiwan, they are from the EPS database of Academia Sinica in Taipei.

For all countries except Australia we use the consumer price index as our measure of goods prices. For Australia we use the wholesale price index. For all countries except Taiwan the price data are from International Einancial Statistics. For Taiwan, the source is the same as the exchange rate data. 


\section{Empirical Results}

We look at the bivariate returns for each pair of countries. This means that there are 55 relative rates of return we can study. There is an issue of whether we should examine each of the 55 relative rates separately, since they are not independent. For example, the forecast of the retum on Australian equities relative to Japanese equities should equal the forecast of the Australian/U.S. retum less the U.S./Japanese retum. A full simultaneous general equilibrium econometric model that forecast each of the returns relative to the U.S., for example, would not require any separate examination of the remaining 45 relative rates of return. However, such a model would require that all information used to forecast any relative retum be included in each relative retum equation. Given our limited data set, such a full-blown simultaneous estimation is impractical. Hence, with estimation done equation by equation for each relative return, and with a small set of regressors included in the forecasting equation, separate information can be obtained from each of the 55 relative return forecasts. That is, we do not impose the constraint that our constructed forecasts of the Australian/Japanese relative return equal the Australian/U.S. return less the U.S./Japanese return.

Table 2 contains some summary statistics for returns in the U.S relative to the other countries. Table 2 is useful for pointing out some of the regularities that run through much of the data. Looking at the first block of Table 2, the variable USAJAPY is the ex post real return on equities in the U.S. relative to Japan. USAJAPX is the ex post nominal return on equities in the U.S. relative to Japan. USAJAPZ is the ex post real depreciation of the dollar. FORY is the forecast of USAJAPY. FORX is the forecast

of USAJAPX, and FORZ is the forecast of USAJAPZ. MYY is the sample second moment of the forecasted relative real return on equities. MXY is the sample cross moment of the 
forecasted relative real return on equities with the forecasted nominal return on equities. $M Z Y=M Y Y-M X Y$, is the sample cross moment of the forecasted relative real return on equities with the forecasted real depreciation of the currency.

The average forecast values of the variables of interest generally have the same sign as the average ex post values, although not in every case. The standard deviations of the forecasts, not surprisingly, are smaller than the standard errors of the ex post realizations.

The absolute size of the average real return differential is larger for Chile, Mexico, Thailand and Taiwan relative to each other and the other seven countries than the real return differentials for those other seven countries relative to each other.

The absolute value of the nominal return differential (both ex post and ex ante) is very large relative to the average change in the real exchange rate. Furthermore, again both ex post and ex ante, the standard error of the change in the real exchange rate is small compared to the standard error of the nominal return differential.

It is very difficult to detect any pattern in the size of the second moments across countries. Based on the Dornbusch sticky-price model, one might have thought that those countries with highly flexible nominal exchange rates would have large real return differentials arising from large changes in the real exchange rate. However, the MZY for the countries with floating exchange rates (U.S., Canada, Japan and Australia) is not evidently any larger than for those with more controlled exchange rates. If anything, the MZY are larger for the latter countries.

Table 3 contains our calculation of the share of deviations of the ex ante return from zero that we can attribute to deviations from ex ante PPP. Of course, the share attributable to deviations from zero of expected nominal return differentials is just one minus the share reported in Table 3. Most of the real return differential can be attributed to nominal return differentials over the vast majority of the relative rates 
we examine. In fact, usually the expected change in the real exchange rate has the effect of drawing the ex ante real return differential closer to zero than the ex ante nominal return differential.

There also does not appear, from Table 3, to be any relation between the role of the expected real exchange rate change in determining the real return differential and the type of exchange rate system operating in the various countries.

Table 4 performs some tests to see whether countries that tended to have high nominal exchange rate variability also tended to have higher shares of real return differentials caused by deviations from ex ante PPP. The dependent variable in these regressions is the shares of real return differentials caused by PPP differentials. The first equation regresses this share against the variance in the monthly log changes in the exchange rate for all 55 pairs of countries. Although the relation is positive, it is not statistically significant. When we add in the mean percentage change as a way to control for exchange rates that had large secular changes during our sample period, the variance of changes still has a positive coefficient, but again is not significant. When we perform the same regressions using only returns on U.S. investments relative to the other countries, the relation is now negative -- the more variable the exchange rate, the lower the share of real return differentials that we can attribute to real exchange rate changes. In the regression without the mean included, the negative relationship is strongly significant.

In short, we find that expected real rates of return are different across the Pacific Basin because expected nominal rates of return are different. There is not a strong relation between the behavior of nominal exchange rates and the share of ex ante real return differentials that we can attribute to expected changes in real exchange rates. 
IV. Conclusions

We have noted that expected changes in the real exchange rate do not seem to be the primary factor in determining the difference in real returns across Pacific Rim countries. This result seems to conflict with earlier findings of Frankel $(1986,1992)$, but several important caveats should be noted.

First, we do not control for risk. While we believe it is more appropriate to look at equities rather than interest-bearing assets if we are to determine the factors underlying patterns of investment in plant and equipment across countries, we must recognize that one important reason that equity returns vary from country to country is because of the difference in the riskiness of the investments. Hence, finding that the expected nominal return differential accounts for most of the expected real return differential on stocks does not necessarily imply that restrictions to capital mobility are high. They may be low, and the market is simply properly rewarding risk-taking activity.

Second, our measures of expectations assume investors have rational expectations. While that is a common assumption in empirical finance, the work of Frankel and Froot (1989) and Froot and Frankel (1990) calls it into question. Their analysis of survey data suggest that there are persistent biases in market participants' forecasts.

Third, even if expectations are rational, it is very difficult to measure the expectations without direct survey evidence. Hence, we inevitably are introducing large errors into our measures of expectations. While we have argued that there should be no inconsistency in large samples with our statistics, experience indicates that sample sizes for models in which expectations are constructed need to be very large before we can be confident of our measures. Here, we are restricted by the data to use series that are no longer than seven years. In many cases, this may be insufficient to construct 
reliable statistics.

It appears that there are large expected return differentials across countries in the Pacific Rim. The question that is left to future research is a finer understanding of why these differentials persist. Is it because of risk or because of barriers to international flows of capital? 
References

Cheng, H.S. 1986. Einancial Rolicy and Beform in Bacific Basin Countries. Lexington, Mass: Lexington Books.

Chinn, M. and J. Frankel. 1992. Financial and Currency Links in Asia and the Pacific. Manuscript, University of California, Santa Cruz.

Dornbusch, R. 1976. Expectations and Exchange Rate Dynamics. Loumal of Political Economy 84: 1161-76.

Economist Publications, The. 1988. Directory of World Stock Exchanges. Baltimore: Johns Hopkins University Press.

Engel, C. and K. Kletzer. 1989. Saving and Investment in an Open Economy with Non-Traded Goods. International Economic Review 30: 735-752.

Feldstein, M. and C. Horioka. 1980. Domestic Saving and International Capital Flows. Economic Joumal 90: 314-29.

Frankel, J. 1986. International Capital Mobility and Crowding-out in the U.S. Economy: Imperfect Integration of Financial Markets or Goods Markets? In How Open is the U.S. Economy? ed. R. Hafer, 33-67. Lexington, Mass: Lexington Books.

1991. Quantifying International Capital Mobility in the 1980s. In National Saving and Economic Performance, eds. B.D. Bernheim and J. Shoven, 227-250. Chicago: University of Chicago Press.

1992. Measuring International Capital Mobility: A Review. American Economic Beview 82: 197-202.

and K. Froot. 1987. Using Survey Data to Test Standard Propositions Regarding Real Exchange Rate Expectations. American Economic Review 77: 133-53.

and S.J. Wei. 1992. Yen Bloc or Dollar Bloc: Exchange Rate Policies of the East Asian Economies. Manuscript, University of California, Berkeley.

Froot, K. and J. Frankel. 1989. Forward Discount Bias: Is it an Exchange Risk Premium? Quarterly Journal of Economics 104: 139-161.

Glick, R. 1987. Interest Rate Linkages in the Pacific Basin. Federal Reserve Bank of San Francisco Economic Reviews no. 3, 31-42.

and M. Hutchison. 1990. Financial Liberalization in the Pacific Basin:

Implications for Real Interest Rate Linkages. Joumal of the Lapanese and International Economies 4: 36-48. 
International Finance Corporation. 1990. Emerging Stock Markets Eactbook.

Razin, A. 1984. Capital Movements, Intersectoral Resource Shifts and the Trade Balance. European Economic Review 26: 135-52. 
</ref_section> 
Table 1

Growth of Stock Markets

\begin{tabular}{|l|r|r|r|c|}
\hline Country & Capitalization & Capitalization & \#1rms listed & flrms listed \\
& 1980 & 1989 & 1980 & 1989 \\
& (\$US millions) & (\$US m1l110ns) & & \\
\hline Japan & 370,200 & $4,392,597$ & 1402 & 2019 \\
U.S. & $1,448,120$ & $3,505,686$ & 6251 & 6727 \\
Canada & 118,300 & 291,328 & 731 & 1146 \\
Austral1a & 59,700 & 136,626 & 1007 & 1335 \\
Singapore & 24,418 & 35,925 & 103 & 136 \\
Taiwan & 48,634 & 237,012 & 102 & 181 \\
Korea & 3,829 & 140,946 & 352 & 626 \\
Malaysia & 12,395 & 39,842 & 182 & 251 \\
Thalland & 1,206 & 25,648 & 77 & 175 \\
Chile & 9,400 & 9,587 & 265 & 213 \\
Mexlco & 12,994 & 22,550 & 271 & 203 \\
\hline
\end{tabular}


Table 2

Summary Statistics

\begin{tabular}{|c|c|c|c|c|c|c|}
\hline SERIES & $\underline{\text { OBS }}$ & MEAN & SID ERROR & & & \\
\hline USAJAPY & 100 & -0.0003376 & 0.055773 & MYY & $=$ & 0.0007949 \\
\hline USAJAPZ & 100 & 0.0047692 & 0.037539 & & & \\
\hline USAJAPX & 100 & -0.0051068 & 0.072914 & MEY & $=$ & 0.0000636 \\
\hline FORY & 75 & -0.0035397 & 0.028159 & & & \\
\hline FORZ & 75 & 0.0033539 & 0.019080 & $M X Y$ & $=$ & 0.0007313 \\
\hline FORX & 75 & -0.0068936 & 0.031655 & & & \\
\hline USACANY & 100 & 0.0064649 & 0.032131 & MYY & $=$ & 0.0002045 \\
\hline USACANZ & 100 & 0.0008201 & 0.011928 & & & \\
\hline USACANX & 100 & 0.0056448 & 0.032950 & $M Z Y$ & $=$ & -0.0000082 \\
\hline FORY & 75 & 0.0038543 & 0.013865 & & & \\
\hline FORZ & 75 & -0.0002411 & 0.005052 & MXY & $=$ & 0.0002127 \\
\hline FORX & 75 & 0.0040954 & 0.015298 & & & \\
\hline USAAUSY & 99 & -0.0017089 & 0.064185 & MYY & $=$ & 0.0009744 \\
\hline USAAUSZ & 99 & -0.0000962 & 0.031020 & & & \\
\hline USAAUSX & 99 & -0.0016126 & 0.076461 & $M Z Y$ & $=$ & -0.0000585 \\
\hline FORY & 74 & -0.0076150 & 0.030479 & & & \\
\hline FORZ & 74 & 0.0011029 & 0.009693 & $M X Y$ & $=$ & 0.001033 \\
\hline FORX & 74 & -0.0087179 & 0.033464 & & & \\
\hline USACHLY & 100 & -0.015285 & 0.075572 & MYY & $=$ & 0.0006420 \\
\hline USACHIZ & 100 & -0.002504 & 0.019489 & & & \\
\hline USACHLX & 100 & -0.012782 & 0.078293 & $M Q Y$ & $=$ & -0.0000032 \\
\hline FORY & 75 & -0.019970 & 0.015702 & & & \\
\hline FORZ & 75 & -0.003948 & 0.010643 & $M X Y$ & $=$ & 0.0006452 \\
\hline FORX & 75 & -0.016021 & 0.023228 & & & \\
\hline USAKORY & 100 & -0.0054688 & 0.073486 & MYY & $=$ & 0.01187 \\
\hline USAKORZ & 100 & 0.0015328 & 0.019311 & & & \\
\hline USAKORX & 100 & -0.0070016 & 0.076148 & $M Z Y$ & $=$ & 0.0003560 \\
\hline FORY & 75 & -0.0045964 & 0.10958 & & & \\
\hline FORZ & 75 & 0.0021502 & 0.011949 & $M X Y$ & $=$ & 0.01151 \\
\hline FORX & 75 & -0.0067466 & 0.10695 & & & \\
\hline USAMALY & 77 & 0.0017253 & 0.085450 & MYY & $=$ & 0.005234 \\
\hline USAMALZ & 77 & -0.0034767 & 0.013595 & & & \\
\hline USAMALX & 77 & 0.0052020 & 0.085686 & MZY & $=$ & 0.0002617 \\
\hline FORY & 52 & 0.025331 & 0.068427 & & & \\
\hline FORZ & 52 & -0.0010558 & 0.010260 & $M X Y$ & $=$ & 0.004972 \\
\hline FORX & 52 & 0.026387 & 0.064615 & & & \\
\hline
\end{tabular}


Table 2 (cont inued)

\begin{tabular}{|c|c|c|c|c|c|c|}
\hline SERIES & $\underline{\mathrm{OBS}}$ & MEAN & STD ERROR & & & \\
\hline USAMEXY & 87 & -0.020356 & 0.15218 & MYY & $=$ & 0.01252 \\
\hline USAMEXZ & 87 & 0.0040949 & 0.066977 & & & \\
\hline USAMEXX & 87 & -0.024451 & 0.17489 & MZY & $=$ & -0.007138 \\
\hline FORY & 62 & -0.017282 & 0.11147 & & & \\
\hline FORZ & 62 & 0.018925 & 0.11897 & MXY & $=$ & 0.01966 \\
\hline FORX & 62 & -0.036207 & 0.20105 & & & \\
\hline USASNGY & 100 & 0.0033971 & 0.071192 & MYY & $=$ & 0.001666 \\
\hline USASNGZ & 100 & 0.0009013 & 0.013841 & & & \\
\hline USASNGX & 100 & 0.0024958 & 0.069348 & MZY & $=$ & -0.0001333 \\
\hline FORY & 75 & -0.0062154 & 0.040616 & & & \\
\hline FORZ & 75 & -0.0007053 & 0.006031 & $M X Y$ & $=$ & 0.001800 \\
\hline FORX & 75 & -0.0055101 & 0.044419 & & & \\
\hline USATWNY & 59 & -0.019109 & 0.15853 & MYY & $=$ & 0.01107 \\
\hline USATWNZ & 59 & 0.0050888 & 0.017570 & & & \\
\hline USATWNX & 59 & -0.024198 & 0.16116 & $M Z Y$ & $=$ & -0.0002214 \\
\hline FORY & 34 & -0.063016 & 0.085524 & & & \\
\hline FORZ & 34 & 0.0062237 & 0.012632 & $M X Y$ & $=$ & 0.01129 \\
\hline FORX & 34 & -0.069240 & 0.084266 & & & \\
\hline USATHLY & 46 & -0.028213 & 0.10484 & MYY & $=$ & 0.004645 \\
\hline USATHLZ & 46 & 0.0006441 & 0.006523 & & & \\
\hline USATHLX & 46 & -0.028857 & 0.010267 & $M Z Y$ & $=$ & 0.0001394 \\
\hline FORY & 21 & -0.038668 & 0.057511 & & & \\
\hline FORZ & 21 & -0.0014036 & 0.003979 & $M X Y$ & $=$ & 0.004506 \\
\hline FORX & 21 & -0.037265 & 0.056330 & & & \\
\hline
\end{tabular}

\section{Abbreviations}

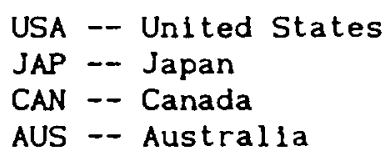

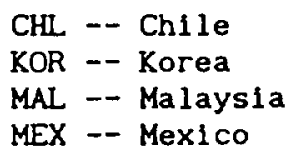

SNG -- Singapore

THL -- Thalland

TWN -- Taiwan 
Table 3

Shares of Real Return Differential "Caused" by Real Exchange Rate Changes

\begin{tabular}{|c|c|c|c|c|c|}
\hline PAIR & SHARE & PAIR & SHARE & PAIR & SHARE \\
\hline USAJAP & 0.08 & CANAUS & 0.12 & CHLSNG & 0.03 \\
\hline USACAN & -0.04 & CANCHL & -0.06 & CHLTWN & 0.0004 \\
\hline USAAUS & -0.06 & CANKOR & -0.05 & CHLTHL & -0.14 \\
\hline USACHL & -0.005 & CANMAL & 0.11 & KORMAL & -0.27 \\
\hline USAKOR & 0.03 & CANMEX & 1.31 & KORMEX & 0.12 \\
\hline USAMAL & 0.05 & CANSNG & -0.34 & KORSNG & -0.60 \\
\hline USAMEX & -0.57 & CANTWN & 0.005 & KORTWN & 0.57 \\
\hline USASNG & -0.08 & CANTHL & 0.08 & KORTHL & -0.20 \\
\hline USATWN & -0.02 & AUSCHL & -0.15 & MALMEX & -0.03 \\
\hline USATHL & 0.03 & AUSKOR & -0.25 & MALSNG & -0.08 \\
\hline JAPCAN & -0.25 & AUSMAL & -0.05 & MALTWN & 0.01 \\
\hline JAPAUS & 0.01 & AUSMEX & -0.05 & MALTHL & -0.07 \\
\hline JAPCHL & -0.10 & AUSSNG & -0.07 & MEXSNG & -0.23 \\
\hline JAPKOR & -0.16 & AUSTWN & 0.14 & MEXTWN & 0.20 \\
\hline JAPMAL & -0.32 & AUSTHL & 0.24 & MEXTHL & -0.53 \\
\hline JAPMEX & -0.14 & CHLKOR & -0.18 & SNGTWN & 0.06 \\
\hline JAPSNG & -0.16 & CHLMAL & 0.03 & SNGTHL & 0.14 \\
\hline JAPTWN & -0.02 & CHLMEX & 0.52 & TWNTHL & -0.002 \\
\hline JAPTHL & 0.01 & & & & \\
\hline
\end{tabular}


Table 4

Regressions of $m(z, y) / m(y, y)$ on Varlance of Log Changes of Exchange Rates

1. ZSHARE $=\left(\begin{array}{l}-0.05 \\ (-0.98)\end{array}+\left(\begin{array}{l}14.7 \\ (0.70)\end{array}\right)\right.$ VRALL

2. ZSHARE $=(-0.04-2.85$ MEANALL +5.10 VRALL

3. ZSHARE $=\left(\begin{array}{l}0.05 \\ (1.39)\end{array}-(-128.5\right.$ VRUS

4. ZSHARE $=0.03+2.85$ MEANUS -75.90 VRUS $(0.90) \quad(1.63) \quad(-1.97)$

ZSHARE $\equiv m(z, y) / m(y, y)$

VRALL $\equiv$ varlance of $l o g$ changes in nominal exchange rates for all 55 bllateral rates.

MEANALL $\equiv$ mean of $\log$ changes in nominal exchange rates for all 55 bilateral rates.

VRUS $\equiv$ varlance of log changes in nominal exchange rates for 10 bilateral rates relative to U.S.

MEANUS $\equiv$ mean of $\log$ changes in nominal exchange rates for 10 bilateral rates relative to U.S.

(t-statistics in parentheses) 